WSRC-RP-2003-00329

KEY WORDS:

Saltstone Disposal

\title{
Potential Enhancement of the Saltstone Inadvertent Intruder Analysis
}

\author{
Author
}

E.L. Wilhite

Westinghouse Savannah River Company

March 28, 2003

Westinghouse Savannah River Company Savannah River Site Aiken, SC 29808

Prepared for the U.S. Department of Energy under Contract No. DE-AC09-96SR18500 
This document was prepared in conjunction with work accomplished under Contract No. DE-AC09-96SR18500 with the U. S. Department of Energy.

\section{DISCLAIMER}

This report was prepared as an account of work sponsored by an agency of the United States Government. Neither the United States Government nor any agency thereof, nor any of their employees, makes any warranty, express or implied, or assumes any legal liability or responsibility for the accuracy, completeness, or usefulness of any information, apparatus, product or process disclosed, or represents that its use would not infringe privately owned rights. Reference herein to any specific commercial product, process or service by trade name, trademark, manufacturer, or otherwise does not necessarily constitute or imply its endorsement, recommendation, or favoring by the United States Government or any agency thereof. The views and opinions of authors expressed herein do not necessarily state or reflect those of the United States Government or any agency thereof.

This report has been reproduced directly from the best available copy.

Available for sale to the public, in paper, from: U.S. Department of Commerce, National Technical Information Service, 5285 Port Royal Road, Springfield, VA 22161, phone: (800) 553-6847, fax: (703) 605-6900

email: orders@ntis.fedworld.gov

online ordering: http://www.ntis.gov/help/index.asp

Available electronically at http://www.osti.gov/bridge

Available for a processing fee to U.S. Department of Energy and its contractors, in paper, from: U.S. Department of Energy, Office of Scientific and Technical Information, P.O. Box 62, Oak Ridge, TN 37831-0062,

phone: (865)576-8401,

fax: (865)576-5728

email: $\underline{\text { reports@ adonis.osti.gov }}$ 


\section{Introduction}

In 2002, a Special Analysis (SA) ${ }^{1}$ was conducted to develop radionuclide disposal limits for low curie salt and other salt wastes in the Saltstone Disposal Facility (SDF). This Special Analysis was done to update the Saltstone Performance Assessment $(\mathrm{PA})^{2}$, which had assumed that only waste from the InTank Precipitation process and the Effluent Treatment Facility would be disposed in Saltstone and to address requirements of the new DOE Waste Management Order, DOE 435.1 ${ }^{3}$. In the SA, limits on radionuclide inventory and concentration were calculated for each radionuclide and each of the requisite pathways (i.e., groundwater, air, radon emanation, and inadvertent intruder). The SA assumed the design of saltstone vault number four would be used for all subsequent vaults. To obtain a disposal limit for ${ }^{126} \mathrm{Sn}$ that provided a margin of an order of magnitude greater than the expected

${ }^{126} \mathrm{Sn}$ content of low curie salt, an additional one meter thick concrete layer was assumed to be added to the vault roof at closure. The additional meter served two functions. It provided a barrier that the intruder would not penetrate so that actual contact with the waste was precluded. Thus, the agriculture scenario, which generally gives lower disposal limits than the residential scenario, was not credible. It also ensured that enough shielding was available in the residential scenario to provide sufficiently high disposal limits.

In February of 2003, a proposal was advanced to avoid the projected $\$ 100$ million to $\$ 300$ million cost of the added concrete ${ }^{4}$. The proposal called for a study to identify potential changes in inputs or assumptions to the saltstone performance assessment, which is now being revised ${ }^{5}$, that would result in not needing the additional concrete. If the study concludes that input changes are not likely to mitigate the need for the additional concrete, then changing the dose limit for the inadvertent intruder from $100 \mathrm{mrem}$ in a year to $500 \mathrm{mrem}$ in a year, to be consistent with Nuclear Regulatory Commission requirements for commercial low-level waste (LLW) disposal ${ }^{6}$, should be considered.

Since the Saltstone $\mathrm{SA}^{1}$ only took credit for the additional one meter of material over the vault roof in the intruder calculations, this study will only consider the intruder, not the groundwater, air, or radon emanation pathways.

\section{Discussion}

Although the one meter of additional material to be placed over the saltstone vaults at closure was described as grout or concrete in the SA, it actually only need be soil. In the SA inadvertent intruder analysis, the intruder's excavation is limited to three meters in depth. The original closure concept for saltstone consisted essentially of two zones of earthen material (Figure 1); an upper zone of 91-cm thickness and a lower zone of 201-cm thickness. The upper zone does not contain any gravel, while the uppermost portion of the lower zone contains a layer of gravel. As discussed in the SA, the gravel is likely to prevent erosion. Thus, over time, the upper zone will erode (the SA assumed that it would be completely eroded by 1,000 years after closure) but the gravel will prevent erosion of any of the lower zone. Since the intruder's excavation can only penetrate to a depth of three meters, the amount of shielding in the residential scenario varies over time from $150 \mathrm{~cm}$ at 100 years, whether the additional material is soil or concrete, to $50 \mathrm{~cm}$ at 1,000 and 10,000 years.

There are a number of factors in the intruder analysis that influence the results, which could potentially be changed to limit the amount of additional material needed over the vault roof. These include the waste dilution factor, the durability of the vault roof and clean grout between the roof and saltstone, which determines whether a physical barrier that cannot be penetrated in an intruder excavation is present or not, the time frame of the analysis, the period over which institutional controls can be assumed to prevent intrusion, and the intruder dose limit. These are discussed below, 
following a brief discussion of intruder analysis and the impact of removing the 1 meter of additional material over the vault.

\section{$\underline{\text { Intruder Analysis }}$}

The inadvertent intruder analysis required by DOE 435.1 does not involve simulation of complex natural phenomena like the groundwater, air, and radon analyses. Rather, the intruder analysis involves the assumption that an inadvertent intrusion event will occur at some time during the period of analysis. Potential actions that such an intruder would take are postulated (e.g., drilling a well, excavating for construction of a house) and factors influencing the degree of exposure to radiation from the waste (e.g., breathing rate, consumption of produce from a home garden, amount of shielding between the receptor and the waste) are developed. These factors are simply multiplied together to calculate the resulting dose.

DOE 435.1 does not require postulating every conceivable action that a future intruder might take. Rather, PA guidance 7 provides a set of scenarios that should be considered. These scenarios are discovery, residential construction, well drilling, post-construction and post-drilling.

PAs and SAs at SRS ${ }^{1,2,8}$ have taken credit for two particular assumptions. First is the impact of durable concrete structures surrounding the waste. Since the subsurface at SRS consists of soil, sand, and clay, which are easily drilled through or excavated into, the assumption has been made that contact with an intact vault or intact saltstone will prevent further intrusion. Secondly, credit has been taken for the probability of the intrusion event contacting the disposal unit. This has been formulated into a parameter called the "Waste Dilution Factor". The waste dilution factor is simply the ratio of the land area occupied by disposal units (e.g., vaults) divided by the land area of the disposal facility. In the saltstone PA and SA, the waste dilution factor is 0.6. Inherent in this value for the waste dilution factor is the assumption that the intrusion event is restricted to the disposal facility.

In the saltstone $\mathrm{SA}^{1}$, the objective was to develop radionuclide disposal limits that are about an order of magnitude greater than the expected content of low curie salt. Limits were developed in terms of the average concentration within the disposed saltstone. These limits were also stated in terms of total curies in a vault and the average concentration in the liquid salt waste. For ${ }^{126} \mathrm{Sn}$, the expected concentration in low curie salt is $7.50 \times 10^{-7} \mathrm{Ci} / \mathrm{L}$. The radionuclide disposal limit for ${ }^{126} \mathrm{Sn}$ developed in the SA is $2.0 \times 10^{-5} \mathrm{Ci} / \mathrm{L}$, which is determined by the resident intruder scenario at 1,000 years after closure.

The radionuclide disposal limits from the SA (i.e., those assuming the additional one meter of material above the vault roof) are shown in Table 1 versus the expected radionuclide content of low curie salt. Only those radionuclides, which have both a calculated limit and an expected concentration in low curie salt, are shown. The limits include those derived from the resident scenario at 100 years. Limits are shown assuming both a 1,000-year and a 10,000-year time of compliance. For both of these sets of limits, the expected radionuclide concentration in low curie salt is divided by the respective limit to determine the fraction of the limit. The fractions of the limits are summed for both time frames. For the 1,000-year limits, the sum-of-fractions is 0.039 and for the 10,000 -year limits, the sum-of-fractions is 0.04 . In each case, ${ }^{126} \mathrm{Sn}$ dominates the sum-of-fractions. A sum-of-fractions of 1 or less indicates compliance with the performance measure. 


\section{Removal of Additional Material over Vault Roof}

Removal of the additional one meter of material over the vault roof will alter the intrusion scenarios that must be evaluated (see Figure 1). At 100 years, the vault roof remains a physical barrier to the intruder; thus, the amount of shielding in the resident scenario decreases from $150 \mathrm{~cm}$ to $50 \mathrm{~cm}$. At 1,000 years, the vault roof continues to be a barrier to intrusion and the amount of shielding in the resident scenario remains the same at $50 \mathrm{~cm}$. At 10,000 years, however, the vault roof and the clean grout above the saltstone have weathered to soil equivalent material. Since the intruder can excavate to a depth of $300 \mathrm{~cm}$, the excavation will penetrate $50 \mathrm{~cm}$ into the saltstone. Therefore, the agriculture scenario becomes credible.

The radionuclide limits from the SA resident scenario at 100 years (i.e., $150 \mathrm{~cm}$ shielding; Table 4-8 of the SA) can be converted to limits at 100 years with $50 \mathrm{~cm}$ shielding by multiplying by the ratio of the dose coefficient in Table 4-6 of the SA for $1.5 \mathrm{~m}$ shielding to that for $0.5 \mathrm{~m}$ shielding. Radionuclide limits for the agriculture scenario, assuming excavation of $50 \mathrm{~cm}$ of saltstone at 10,000 years, were determined in an unpublished early draft of the SA; these limits include consideration of the resident scenario with no shielding. Table 2 shows the controlling limits at 1,000 years and at 10,000 years considering the resident scenario at 100 years with $50 \mathrm{~cm}$ shielding, the resident scenario at 1,000 years with $50 \mathrm{~cm}$ shielding (i.e., unchanged from the SA), and the agriculture scenario at 10,000 years. Table 2 shows that the sum-of-fractions of the limits at 1,000 years increases from 0.039 to 35 while the sum-of-fractions at 10,000 years increases from 0.04 to 42 . All of the increase at 1,000 years is due to ${ }^{137} \mathrm{Cs}$, while at 10,000 years both ${ }^{126} \mathrm{Sn}$ and ${ }^{137} \mathrm{Cs}$ increase substantially. With no compensatory measures, removal of the additional one meter of material over the vault roof results in non-compliance with the intruder performance measure at both time frames.

\section{$\underline{\text { Waste Dilution Factor }}$}

As stated above, the waste dilution factor is a measure of the probability of the intruder contacting waste. In the SRS PAs ${ }^{2,8}$ and the saltstone $\mathrm{SA}^{1}$, it was assumed that the intrusion event was onto the disposal facility. Thus, the waste dilution factor is the ratio of the land area occupied by disposal units divided by the land area of the disposal facility.

The SRS long-term land use plan ${ }^{9}$ indicates that none of the current 300 -square mile site will be released for unrestricted use. The plan also indicates that certain areas of the site will be restricted to industrial use. One of these areas is the central part of the site, which is called the General Separations Area (GSA). The GSA includes all the low-level waste disposal facilities at SRS.

Even though the entire SRS will remain under Federal control, I do not think it credible to consider the intrusion event as occurring at any location on the 300-square mile site. However, I do think it credible to assume that the intrusion event occurs at any location within the GSA. I assume that the land use plan may change in future to release for unrestricted use some of the SRS lands containing no residual radioactive material. However, I believe the assumption that the GSA will never be released from Federal Control to be very credible. To estimate the impact of this assumption on the waste dilution factor, the SRS geographical information system (GIS) was queried to determine the land area of facilities within the GSA. That land area is $6.2 \times 10^{6}$ square meters ${ }^{10}$. The land area occupied by vaults in the saltstone SA was $156,600 \mathrm{~m}^{2}$. The ratio of these areas is 0.03 . Therefore, changing this assumption would result in the waste dilution factor changing from 0.6 to 0.03 . The intruder dose is directly proportional to the waste dilution factor; thus, using this new assumption would decrease the intruder dose by a factor of 20 . Conversely, the radionuclide inventory limits derived from the intruder scenarios would increase by a factor of 20 . 
Therefore, if the inadvertent intruder analysis used the smaller waste dilution factor, all the limits shown in Tables 1 and 2 would increase by a factor of 20. Thus, the expected concentration in low curie salt divided by the limit would decrease by a factor of 20 and the sum-of-fractions of the limits would also decrease by a factor of 20 . From Table 2, the sum-of-fractions of the limits assuming that the one meter of additional material is not used would decrease to 1.75 for the 1,000 year time of compliance case and to 2.1 for the 10,000-year time of compliance. Therefore, using only the smaller waste dilution factor to compensate for the additional one meter of material above the vault will not result in compliance with the intruder performance measure over either time frame.

\section{Concrete Weathering Rate}

The SRS PAs ${ }^{2,8}$ and the saltstone $\mathrm{SA}^{1}$ address deterioration of the concrete and clean grout by analogy with weathering rates of carbonate rock in regions near the SRS (see Section 3.2.4.1 of reference 2). Weathering rates of carbonate rock range from $3.5 \mathrm{~cm}$ to $10 \mathrm{~cm}$ per 1,000 years at the normal rate of infiltration of rainwater (i.e., about $40 \mathrm{~cm}$ per year). The upper end of this range was used because the saltstone and grout should be more permeable than carbonate rock and, thus, more susceptible to weathering.

A potentially less conservative approach would be to apply the average weathering rate of $6.8 \mathrm{~cm}$ per 1,000 years. However, this would have little effect on the analysis. With this assumption, the vault roof and clean grout would still be intact at 1,000 years. At 10,000 years, $68 \mathrm{~cm}$ would have weathered instead of $100 \mathrm{~cm}$. Thus, all of the vault roof and clean grout would have weathered, but only $18 \mathrm{~cm}$ instead of $50 \mathrm{~cm}$ of the saltstone would have weathered. Thus, there would be no shielding in the residential scenario as discussed above. However, in the agriculture scenario, only 18 $\mathrm{cm}$ instead of $50 \mathrm{~cm}$ of the saltstone would have been excavated. Since the dose in the agriculture scenario is directly proportional to the amount of waste excavated, the effect of using the average weathering rate would be to increase the limits derived from the agriculture scenario (i.e., for all except ${ }^{60} \mathrm{Co},{ }^{137} \mathrm{Cs},{ }^{154} \mathrm{Eu},{ }^{232} \mathrm{U},{ }^{242 \mathrm{~m}} \mathrm{Am}$ ) for the 10,000 -year time frame in Table 2 by 100/68 or a factor of 1.47. Thus, the 10,000-year sum-of-fractions would decrease from 42 to 40 . If both the smaller waste dilution factor and the average weathering rate were used, the 10,000-year sum-offractions would decrease to 2 , which is still not compliant with the intruder performance measure.

\section{Time Frame of Analysis}

The appropriate time frame for the analysis is an issue that will be pursued in the revision of the saltstone PA ${ }^{5}$. Briefly, DOE 435.1 clearly states that the time frame for the PA is 1,000 years. However, DOE 435.1 also requires that, in the sensitivity/uncertainty analysis, the calculations should be carried out beyond 1,000 years to determine the maximum impact regardless of the time at which the maximum occurs ${ }^{7}$. Also, since the waste to be disposed in saltstone arises predominantly from the high-level waste tanks, provisions of the Waste Incidental to Reprocessing (WIR) requirement apply. For WIR waste that will be managed as LLW, DOE requires that the waste be disposed to meet performance objectives comparable to those for commercial LLW waste. Nuclear regulatory commission guidance indicates that PA calculations should be carried out for 10,000 years and beyond except for intruder analysis. For commercial LLW disposal, PAs do not need to analyze the intruder pathway at all; rather, the disposal facility can simply demonstrate that it complies with requirements for stabilizing Class $\mathrm{B} \& \mathrm{C}$ wastes and provides an intruder barrier for Class $\mathrm{C}$ waste. Another potential argument to carry saltstone PA calculations beyond 1,000 years is the continuing interaction with the South Carolina Department of Health and Environmental Control (SCDHEC). The saltstone disposal facility is permitted by SCDHEC as an industrial solid waste landfill. SCDHEC is concerned about the protection of groundwater quality. In the saltstone $\mathrm{SA}^{1}$, disposal limits were calculated for time frames of 1,000 and 10,000 years. For the groundwater pathway at 
1,000 years, no radionuclide limits needed to be calculated (i.e., the rates of release from the vaults and migration to the groundwater were so low that there was no impact at 1,000 years). This may suggest that groundwater pathway impacts should be calculated over a period of 10,000 years, so that groundwater protection will be one of the factors limiting disposal in Z-Area.

However, DOE guidance ${ }^{7}$ for the intruder analysis makes it plain that only qualitative sensitivity and uncertainty analyses are appropriate. This indicates that, for the intruder analysis, calculations should be carried to 1,000 years and no further.

\section{$\underline{\text { Institutional Controls }}$}

The time period over which institutional controls should be assumed to prevent intrusion is another issue that will be pursued in the revision of the saltstone $\mathrm{PA}^{5}$. DOE 435.1 specifies that the minimum time period assumed should be 100 years, which is the period used in the SA and in all SRS PAs to date. However, DOE 435.1 allows the use of longer periods, with justification. At the Hanford site, the performance assessments for the 200-Area burial grounds ${ }^{11,12}$ used both 100 years and 300 years for this time period. The 300-year period was used for concrete wasteforms. I believe it credible to use a period of 300 years on the basis that, given DOE's intent to control the land in perpetuity, the effectiveness of the controls would be greatest in the time following the end of all operations at SRS. Also, since it seems that SRS will have continuing missions following the end of environmental restoration, assuming a period greater than 100 years is logical. Given the view that intrusion is an "accident" caused by a temporary lapse in institutional controls, I don't believe it credible to use a period of much more than 300 years.

The effect of increasing this time period is to provide a longer time for radioactive decay before intrusion can occur. Rather than evaluating the resident intrusion scenario at 100 years, it would be evaluated at 300 years. For ${ }^{137} \mathrm{Cs}$, the only shorter-lived radionuclide that contributes significantly to the sum-of-fractions in Table 2, the fraction remaining after radioactive decay would decrease from 0.1 to 0.001 . This would increase the calculated limit by 100 times, which would decrease the ${ }^{137} \mathrm{Cs}$ fraction of the limit by a factor of 100 . Therefore, if the assumed period of institutional control were to be increased to 300 years, the sum-of-fractions in Table 2 would decrease to 0.39 at 1,000 years and to 7.8 at 10,000 years.

\section{$\underline{\text { Dose Limit }}$}

DOE 435.1 specifies the dose limit to be used in the intruder calculations as $100 \mathrm{mrem} / \mathrm{year}^{3}$. Reference 4 proposes to increase the dose limit to $500 \mathrm{mrem} / \mathrm{year}$ to be consistent with NRC requirements for LLW disposal ${ }^{6}$. The radionuclide disposal limits calculated in the PA or SA are directly proportional to the dose limit. Increasing the dose limit from $100 \mathrm{mrem} / \mathrm{year}$ to 500 $\mathrm{mrem} / \mathrm{year}$ will increase calculated limits by a factor of 5 and will decrease the sum-of-fractions in Table 2 to 7.0 at 1,000 years and to 8.4 at 10,000 years.

\section{Summary}

Table 3 shows the sums-of-fractions of limits for various combinations of analysis assumptions, all of which assume that the additional one meter of material is not placed above the vault roof. For a time of compliance of 10,000 years, only combinations of factors will result in a compliant sum-offractions. For example, increasing institutional control and decreasing the waste dilution factor will reduce the sum-of-fractions to 0.39 However, for a 1,000-year time of compliance, increasing the institutional control period to 300 years will be compliant. 
Figure 1. Saltstone SA Resident Scenario Conceptual Model

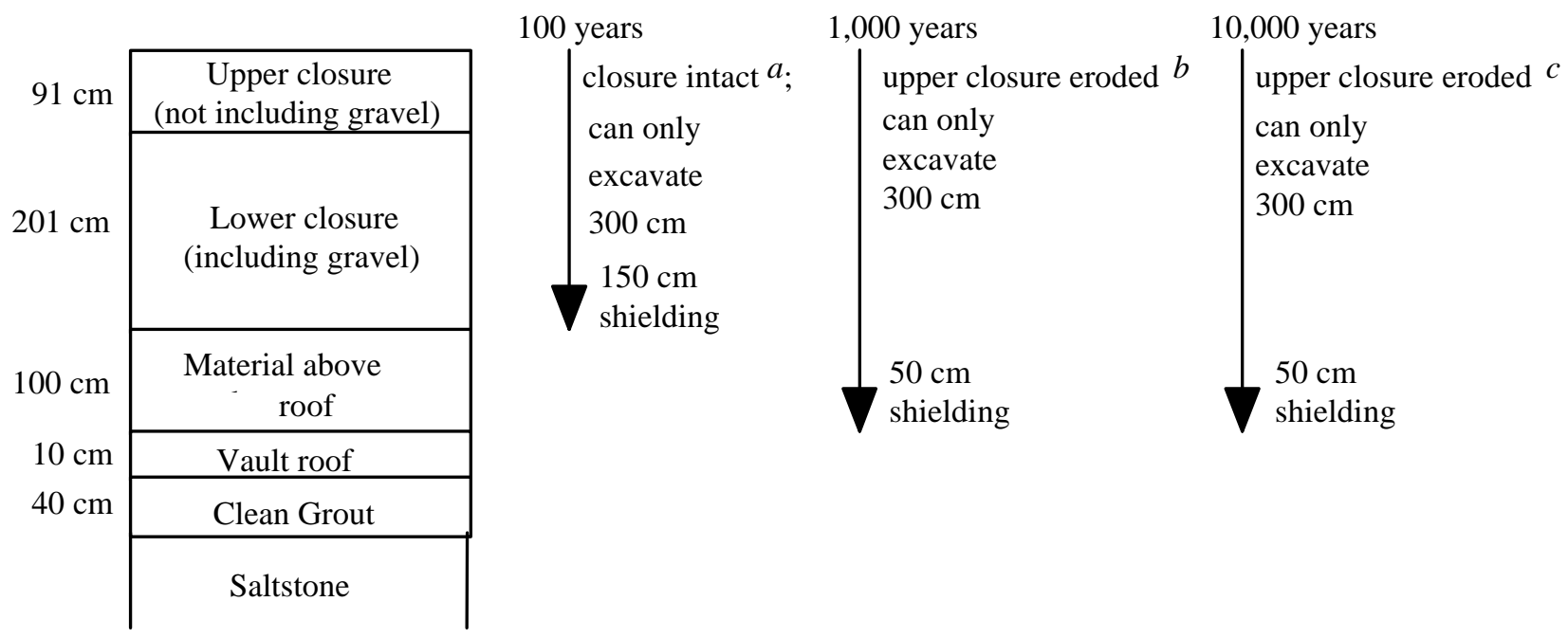

a At 100 years after closure, there has been no erosion and the grout and vault roof have not deteriorated so that they effectively prevent excavation. Therefore, the intruder constructs his residence atop the grout above the vault roof, resulting in a total of $150 \mathrm{~cm}$ of shielding between the residence and the saltstone. If the added one meter of material above the vault roof is soil, then the intruder can only excavate to a depth of 3 meters, which leaves $140 \mathrm{~cm}$ of shielding.

${ }^{b}$ At 1,000 years after closure, erosion has removed the upper $91 \mathrm{~cm}$ of the closure. However, the gravel, which is the uppermost portion of the lower closure, prevents further erosion. The grout and vault roof have deteriorated to soil equivalent material so that they no longer can prevent excavation. Since the intruder's excavation is limited to $300 \mathrm{~cm}$, the residence is constructed on top of the vault roof, resulting in a total of $50 \mathrm{~cm}$ of shielding between the residence and the saltstone.

$c$ At 10,000 years after closure, erosion has not penetrated further than at 1,000 years (i.e., $91 \mathrm{~cm}$ ), because of the gravel layer. Since the intruder's excavation is limited to $300 \mathrm{~cm}$, the residence is constructed on top of the vault roof, resulting in a total of $50 \mathrm{~cm}$ of shielding between the residence and the saltstone. 
Table 1 Saltstone Special Analysis ${ }^{1}$ Radionuclide disposal limits from the Resident Scenario Compared with Estimated Low Curie Salt Composition

\begin{tabular}{cccccc} 
1,000 Year & $\begin{array}{c}\text { 10,000 Year } \\
\text { Controlling } \\
\text { Limit } \\
\text { Radionuclide } \\
\text { Ci/L Solution }\end{array}$ & $\begin{array}{c}\text { Limit } \\
\text { Ci/L Solution }\end{array}$ & $\begin{array}{c}\text { LCS } \\
\text { Salt Solution } \\
\text { Ci/L }\end{array}$ & $\begin{array}{c}1,000 \mathrm{Yr} \\
\text { LCS/Limit }\end{array}$ & $\begin{array}{c}10,000 \mathrm{Yr} \\
\text { LCS/Limit }\end{array}$ \\
\hline Co-60 & $6.0 \mathrm{E}+03$ & $6.0 \mathrm{E}+03$ & $4.1 \mathrm{E}-05$ & $6.9 \mathrm{E}-09$ & $6.9 \mathrm{E}-09$ \\
Sn-126 & $2.0 \mathrm{E}-05$ & $2.0 \mathrm{E}-05$ & $7.5 \mathrm{E}-07$ & $3.8 \mathrm{E}-02$ & $3.8 \mathrm{E}-02$ \\
Cs-137 & $2.0 \mathrm{E}+01$ & $2.0 \mathrm{E}+01$ & $2.3 \mathrm{E}-02$ & $1.1 \mathrm{E}-03$ & $1.1 \mathrm{E}-03$ \\
Eu-154 & $1.5 \mathrm{E}+02$ & $1.5 \mathrm{E}+02$ & $1.0 \mathrm{E}-04$ & $6.7 \mathrm{E}-07$ & $6.7 \mathrm{E}-07$ \\
Th-232 & $3.2 \mathrm{E}-06$ & $3.2 \mathrm{E}-06$ & $2.9 \mathrm{E}-10$ & $9.0 \mathrm{E}-05$ & $9.0 \mathrm{E}-05$ \\
$\mathrm{U}-232$ & $3.0 \mathrm{E}-03$ & $3.0 \mathrm{E}-03$ & $6.2 \mathrm{E}-11$ & $2.1 \mathrm{E}-08$ & $2.1 \mathrm{E}-08$ \\
$\mathrm{U}-233$ & $1.8 \mathrm{E}-03$ & $2.8 \mathrm{E}-04$ & $1.7 \mathrm{E}-08$ & $9.5 \mathrm{E}-06$ & $6.1 \mathrm{E}-05$ \\
$\mathrm{U}-234$ & $3.8 \mathrm{E}-03$ & $9.1 \mathrm{E}-05$ & $6.3 \mathrm{E}-09$ & $1.7 \mathrm{E}-06$ & $6.9 \mathrm{E}-05$ \\
$\mathrm{U}-235$ & $8.7 \mathrm{E}-03$ & $1.8 \mathrm{E}-03$ & $2.0 \mathrm{E}-10$ & $2.3 \mathrm{E}-08$ & $1.1 \mathrm{E}-07$ \\
$\mathrm{U}-238$ & $1.3 \mathrm{E}-03$ & $1.1 \mathrm{E}-03$ & $4.8 \mathrm{E}-09$ & $3.7 \mathrm{E}-06$ & $4.3 \mathrm{E}-06$ \\
Np-237 & $1.1 \mathrm{E}-03$ & $1.1 \mathrm{E}-03$ & $8.9 \mathrm{E}-09$ & $8.1 \mathrm{E}-06$ & $8.1 \mathrm{E}-06$ \\
Pu-238 & $1.3 \mathrm{E}+01$ & $2.6 \mathrm{E}-01$ & $2.2 \mathrm{E}-04$ & $1.7 \mathrm{E}-05$ & $8.4 \mathrm{E}-04$ \\
Pu-239 & & $3.6 \mathrm{E}+02$ & $3.3 \mathrm{E}-06$ & & $9.3 \mathrm{E}-09$ \\
Pu-241 & $2.2 \mathrm{E}+02$ & $1.6 \mathrm{E}+02$ & $1.1 \mathrm{E}-04$ & $4.8 \mathrm{E}-07$ & $6.8 \mathrm{E}-07$ \\
Am-241 & $6.9 \mathrm{E}+00$ & $5.0 \mathrm{E}+00$ & $2.2 \mathrm{E}-05$ & $3.2 \mathrm{E}-06$ & $4.5 \mathrm{E}-06$ \\
Am-242m & $8.3 \mathrm{E}-01$ & $2.0 \mathrm{E}-01$ & $2.1 \mathrm{E}-08$ & $2.5 \mathrm{E}-08$ & $1.1 \mathrm{E}-07$ \\
Cm-242 & $2.6 \mathrm{E}+03$ & $5.2 \mathrm{E}+01$ & $2.2 \mathrm{E}-05$ & $8.5 \mathrm{E}-09$ & $4.2 \mathrm{E}-07$ \\
Cm-245 & $1.3 \mathrm{E}-01$ & $1.3 \mathrm{E}-01$ & $1.6 \mathrm{E}-09$ & $1.3 \mathrm{E}-08$ & $1.3 \mathrm{E}-08$ \\
& & & Sum Fract & $3.9 \mathrm{E}-02$ & $4.0 \mathrm{E}-02$
\end{tabular}

1. Special Analysis: Reevaluation of the Inadvertent Intruder, Groundwater, Air, and Radon Analyses for the Saltstone Disposal Facility, WSRC-TR-2002-00456, Rev. 0, Savannah River Technology Center, Westinghouse Savannah River Company, Aiken, SC., October 23, 2002. 
Table 2 Estimated Radionuclide Disposal Limits Without the 1-m of Additional Material and with no Compensatory Measures Compared with Estimated Low Curie Salt Composition

\begin{tabular}{|c|c|c|c|c|c|}
\hline Radionuclide & $\begin{array}{c}\text { 1,000 Year } \\
\text { Controlling } \\
\text { Limit } \\
\text { Ci/L Solution }\end{array}$ & $\begin{array}{c}\text { 10,000 Year } \\
\text { Controlling } \\
\text { Limit } \\
\text { Ci/L Solution }\end{array}$ & $\begin{array}{c}\text { LCS } \\
\text { Salt Solution } \\
\text { Ci/L }\end{array}$ & $\begin{array}{c}1,000 \mathrm{Yr} \\
\text { LCS/Limit }\end{array}$ & $\begin{array}{l}\text { 10,000 Yr } \\
\text { LCS/Limit }\end{array}$ \\
\hline C-14 & & $3.6 \mathrm{E}-04$ & $4.5 \mathrm{E}-10$ & & $1.2 \mathrm{E}-06$ \\
\hline Co-60 & $2.4 \mathrm{E}+00$ & $2.4 \mathrm{E}+00$ & 4.1E-05 & 1.7E-05 & 1.7E-05 \\
\hline $\mathrm{Ni}-59$ & & $2.4 \mathrm{E}-02$ & 2.6E-07 & & 1.1E-05 \\
\hline Se-79 & & 1.3E-03 & $1.5 \mathrm{E}-07$ & & $1.2 \mathrm{E}-04$ \\
\hline Tc-99 & & $1.0 \mathrm{E}-02$ & 2.6E-06 & & 2.5E-04 \\
\hline Sn-126 & $2.0 \mathrm{E}-05$ & $1.1 \mathrm{E}-07$ & 7.5E-07 & 3.8E-02 & $7.1 E+00$ \\
\hline $\mathrm{I}-129$ & & 1.6E-05 & $2.4 \mathrm{E}-11$ & & $1.5 \mathrm{E}-06$ \\
\hline Cs-135 & & 1.3E-03 & 1.8E-09 & & $1.4 \mathrm{E}-06$ \\
\hline Cs-137 & $6.5 \mathrm{E}-04$ & $6.5 \mathrm{E}-04$ & 2.3E-02 & $3.5 E+01$ & $3.5 E+01$ \\
\hline Eu-154 & 4.0E-02 & 4.0E-02 & 1.0E-04 & $2.5 \mathrm{E}-03$ & $2.5 E-03$ \\
\hline Th-232 & $3.2 E-06$ & $7.5 E-08$ & $2.9 E-10$ & 9.0E-05 & 3.8E-03 \\
\hline U-232 & $9.1 \mathrm{E}-06$ & $9.1 \mathrm{E}-06$ & $6.2 \mathrm{E}-11$ & $6.9 E-06$ & 6.9E-06 \\
\hline U-233 & 1.8E-03 & $1.1 \mathrm{E}-06$ & 1.7E-08 & 9.5E-06 & 1.6E-02 \\
\hline U-234 & $3.8 \mathrm{E}-03$ & 1.4E-06 & $6.3 \mathrm{E}-09$ & 1.7E-06 & 4.4E-03 \\
\hline U-235 & 8.7E-03 & $9.1 \mathrm{E}-07$ & $2.0 \mathrm{E}-10$ & 2.3E-08 & 2.2E-04 \\
\hline U-236 & & 5.2E-05 & $9.6 \mathrm{E}-10$ & & 1.9E-05 \\
\hline U-238 & 1.3E-03 & 7.1E-06 & 4.8E-09 & 3.7E-06 & 6.7E-04 \\
\hline Np-237 & 1.1E-03 & 8.7E-07 & 8.9E-09 & 8.1E-06 & 1.0E-02 \\
\hline Pu-238 & $1.3 E+01$ & 4.2E-03 & 2.2E-04 & 1.7E-05 & $5.2 \mathrm{E}-02$ \\
\hline Pu-239 & & 2.2E-05 & 3.3E-06 & & $1.5 \mathrm{E}-01$ \\
\hline $\mathrm{Pu}-240$ & & $5.0 \mathrm{E}-05$ & 1.6E-06 & & 3.1E-02 \\
\hline $\mathrm{Pu}-241$ & $2.2 E+02$ & 1.3E-01 & 1.1E-04 & 4.8E-07 & $8.1 \mathrm{E}-04$ \\
\hline $\mathrm{Pu}-242$ & & 1.8E-05 & 3.6E-09 & & 2.0E-04 \\
\hline Am-241 & $6.9 E+00$ & $4.4 \mathrm{E}-03$ & 2.2E-05 & $3.2 E-06$ & 5.1E-03 \\
\hline$A m-242 m$ & 1.0E-02 & 1.0E-02 & 2.1E-08 & 2.1E-06 & 2.1E-06 \\
\hline $\mathrm{Cm}-242$ & $2.6 \mathrm{E}+03$ & 8.3E-01 & 2.2E-05 & 8.5E-09 & 2.6E-05 \\
\hline \multirow[t]{2}{*}{$\mathrm{Cm}-245$} & 1.3E-01 & $5.0 \mathrm{E}-06$ & 1.6E-09 & 1.3E-08 & 3.3E-04 \\
\hline & & & Sum Fract & $3.5 \mathrm{E}+01$ & $4.2 \mathrm{E}+01$ \\
\hline
\end{tabular}


Table 3 Sum-of-Fractions Without Additional Meter of Material above Vault

\begin{tabular}{ccc} 
& \multicolumn{2}{c}{ Time of Compliance } \\
Analysis Component & 1,000 Years & 10,000 Years \\
\hline Original $^{*}$ & 35 & 42 \\
\hline Decrease Waste Dilution Factor & 1.75 & 2.1 \\
\hline Use Average Weathering Rate & 35 & 40 \\
\hline Increase Institutional Control to 300 years & 0.039 & 7.8 \\
\hline Increase Dose Limit to 500 mrem/year & 7.0 & 8.4 \\
\hline
\end{tabular}

Increase Institutional Control to 300 years
and
0.002
0.39

Decrease Waste Dilution Factor

Increase Dose Limit
and
0.35
0.42

Decrease Waste Dilution Factor

Increase Dose Limit

$\begin{array}{lll}\text { and } & 0.0078 & 1.56\end{array}$

Increase Institutional Control to 300 years

Increase Dose Limit

and

Increase Institutional Control to 300 years $\quad 0.0004 \quad 0.078$

and

Decrease Waste Dilution Factor

* Waste Dilution Factor $=0.6$, Concrete weathering rate $=10 \mathrm{~cm} / 1000$ years; 100 years of institutional control; Dose limit $=100 \mathrm{mrem} /$ year 


\section{References}

1. Special Analysis: Reevaluation of the Inadvertent Intruder, Groundwater, Air, and Radon Analyses for the Saltstone Disposal Facility, WSRC-TR-2002-00456, Rev. 0, Savannah River Technology Center, Westinghouse Savannah River Company, Aiken, SC., October 23, 2002.

2. Radiological Performance Assessment for the Z-Area Saltstone Disposal Facility, WSRC-RP-921360, Rev. 0, Westinghouse Savannah River Company, Aiken, SC., December 18, 1992.

3. Radioactive Waste Management, Order, Manual, and Implementation Guide 435.1, U.S. Department of Energy, July 9, 1999.

4. Memorandum, W.J. Johnson to C.E. Anderson, Recommended Changes to DOE Order 435.1, CBU-2002-00021, 2/21/2003.

5. Program Plan for Updating the Saltstone Disposal Facility Performance Assessment, WSRC-RP2002-00637, Savannah River Technology Center, Westinghouse Savannah River Company, Aiken, SC., December 20, 2002.

6. Licensing Requirements for Land Disposal of Radioactive Waste, 10 CFR 61.

7. Format and Content Guide for U.S. Department of Energy Low-Level Waste Disposal Facility Performance Assessments and Composite Analyses, U.S. Department of Energy, December 7, 1999.

8. Radiological Performance Assessment for the E-Area Low-Level Waste Facility, WSRC-RP-94218, Rev. 1, Savannah River Technology Center, Westinghouse Savannah River Company, Aiken, SC., January 31, 2000.

9. Composite Analysis E-Area Vaults and Saltstone Disposal Facilities, WSRC-RP-97-311Rev. 0, Westinghouse Savannah River Company, Aiken, SC., September 1997.

10. SRS Metadata, SRS Facility Areas (ID 11200015200212001).

11. Performance Assessment for the Disposal of Low-Level Waste in the 200 West Area Burial Grounds, WHC-EP-0645, Westinghouse Hanford Company, Richland, Washington, June 1995.

12. Performance Assessment for the Disposal of Low-Level Waste in the 200 East Area Burial Grounds, WHC-EP-0875, Westinghouse Hanford Company, Richland, Washington, September 1996. 